\title{
Effect of Shear Wall Area on Seismic Behaviour of Multistoried Building with Soft Storey At Ground Floor
}

\author{
Ejaz Ahmad Bhat \\ M. tech \\ Al-Falah University, Faridabad Haryana
}

\author{
Mr. Faiyaz Azam \\ Assistant Professor \\ Al-Falah University, Faridabad Haryana
}

\begin{abstract}
The trend towards progressively taller structures has demanded a shift from the traditional strength based design approach of buildings, to a focus on constraining the overall motion of the structure. Now a day's reinforced concrete (RC) wall-frame buildings are widely recommended for urban construction in areas which are prone to earthquake. Construction of shear walls imparts a large stiffness to the lateral force resisting system of the RC building. Proper detailing of shear walls can also lead to ductile behavior of such structures during strong earthquake shaking. One of the main parameters influencing the seismic behavior of shear wall frame buildings is the shear wall area ratio and shear wall area ratio need to be studied. Thus an analytical study is performed to evaluate the effect of Shear Wall Area to floor area ratio (SWA/FA) on the seismic behavior of multistoried RC structures with soft storey at ground floor. For this purpose, 9 building models that have Five, Nine and Twelve stories with various SWA/FA in both directions are generated. Then, the behavior of these building models under earthquake loading is examined by carrying out Response Spectrum Analysis and Linear Static Analysis using structural analysis software Etabs. Response Spectrum Analysis and Linear Static both are carried out according to seismic code IS 1893:2002
\end{abstract}

Key words: Reinforced concrete; Shear wall; Response spectrum; Linear static analysis; Earthquake resistant structures.

\section{INTRODUCTION}

Over the few decades, shear walls are widely used in countries especially where chances of earthquake are very high. Shear walls are designed not only to resist gravity loads but also withstand the overturning moments as well as shear forces. The major factors for inclusion of shear walls are ability to minimize lateral drifts, interstorey displacement and excellent performance in past earthquake record. They have very large in plane stiffness that limit the amount of lateral displacement of the building under lateral loadings. Shear walls are intended to behave elastically during moderate or low seismic loading to prevent non-structural damage in the building. However, it is expected that the walls will be exposed to inelastic deformation during less or frequent earthquakes. Thus, shear walls must be designed to withstand forces that cause inelastic deformations while maintaining their ability to carry load and dissipate energy. Structural and non-structural damage is expected during severe earthquakes however; collapse prevention and life safety is the main concern in the design. To minimize loss after earthquakes, the experimental and analytical studies on seismic design approaches encourage use of shear walls for earthquake-resistant design. The effect of shear wall ratio on structural vulnerability could be evaluated by the variation of different parameters such as roof or inter storey drift with increasing shear wall ratio.

1.2 Definition of Soft Storey:

The main difference between a soft storey and a weak storey is that, while a soft storey is classified based on stiffness or simply the relative resistance to lateral deformation or storey drift and the weak story qualifies on the basis of strength in terms of force resistance (statics) or energy capacity (dynamics).

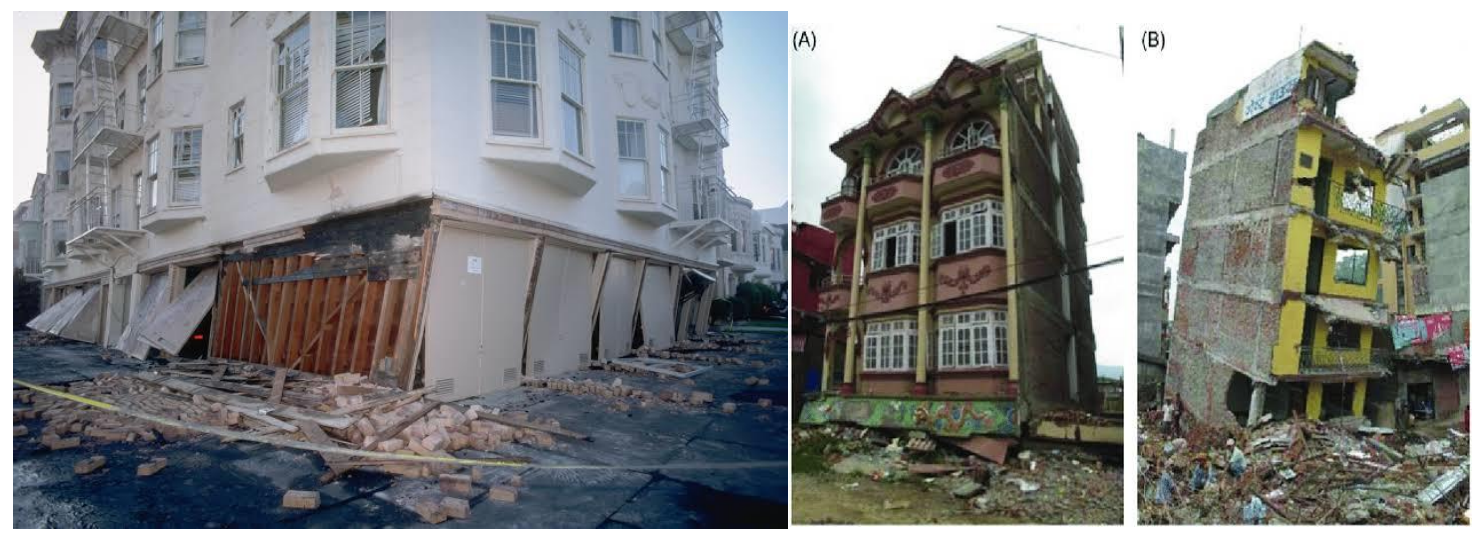




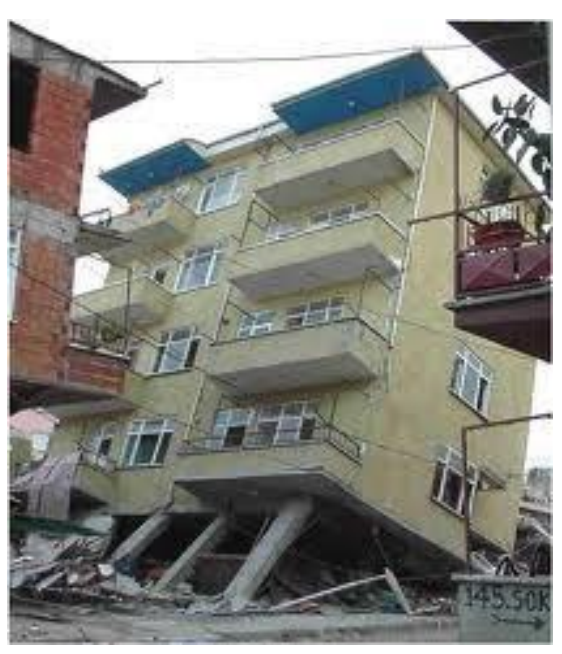

\subsection{Storey Drift}

The drift in a storey is computed as difference of deflection of the floor at the top and bottom of the storey under consideration. The total drift in any storey is the sum of shear deformation of that storey, axial deformation of floor system, overall flex ure of the building and foundation rotation.

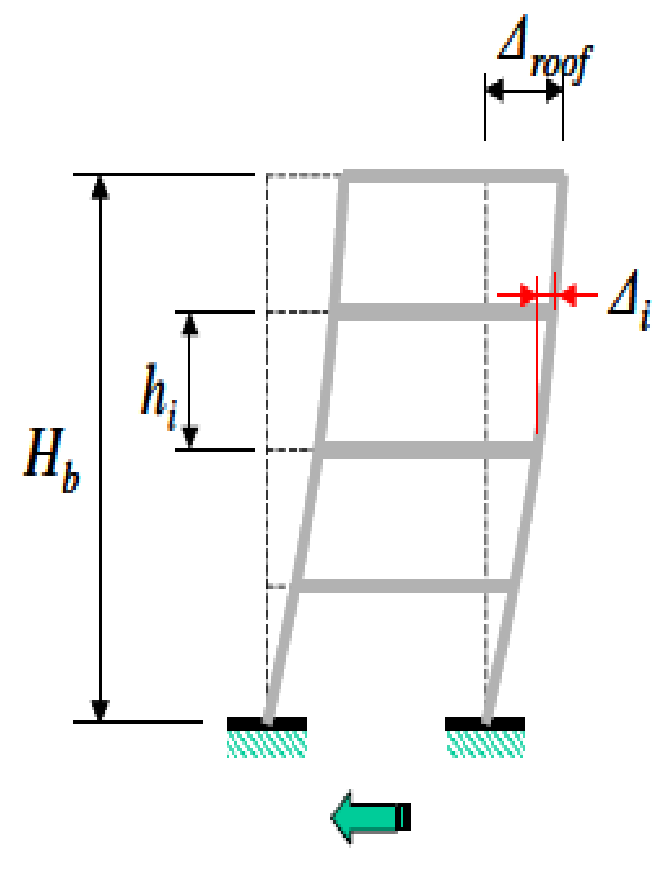

\section{Earthquake Ground motions}

\section{Roof displacement and inter-storey displacement.}

\subsubsection{Behaviour of Shear wall:}

Fig 1.2 Shows the Storey drift

Shear walls are the main vertical structural elements with a dual role of resisting both the gravity and lateral loads. Shear wall constructed in the high rise buildings, generally behave as vertical cantilever beam with their Strength controlled by flexure as shown in fig (1.3). 


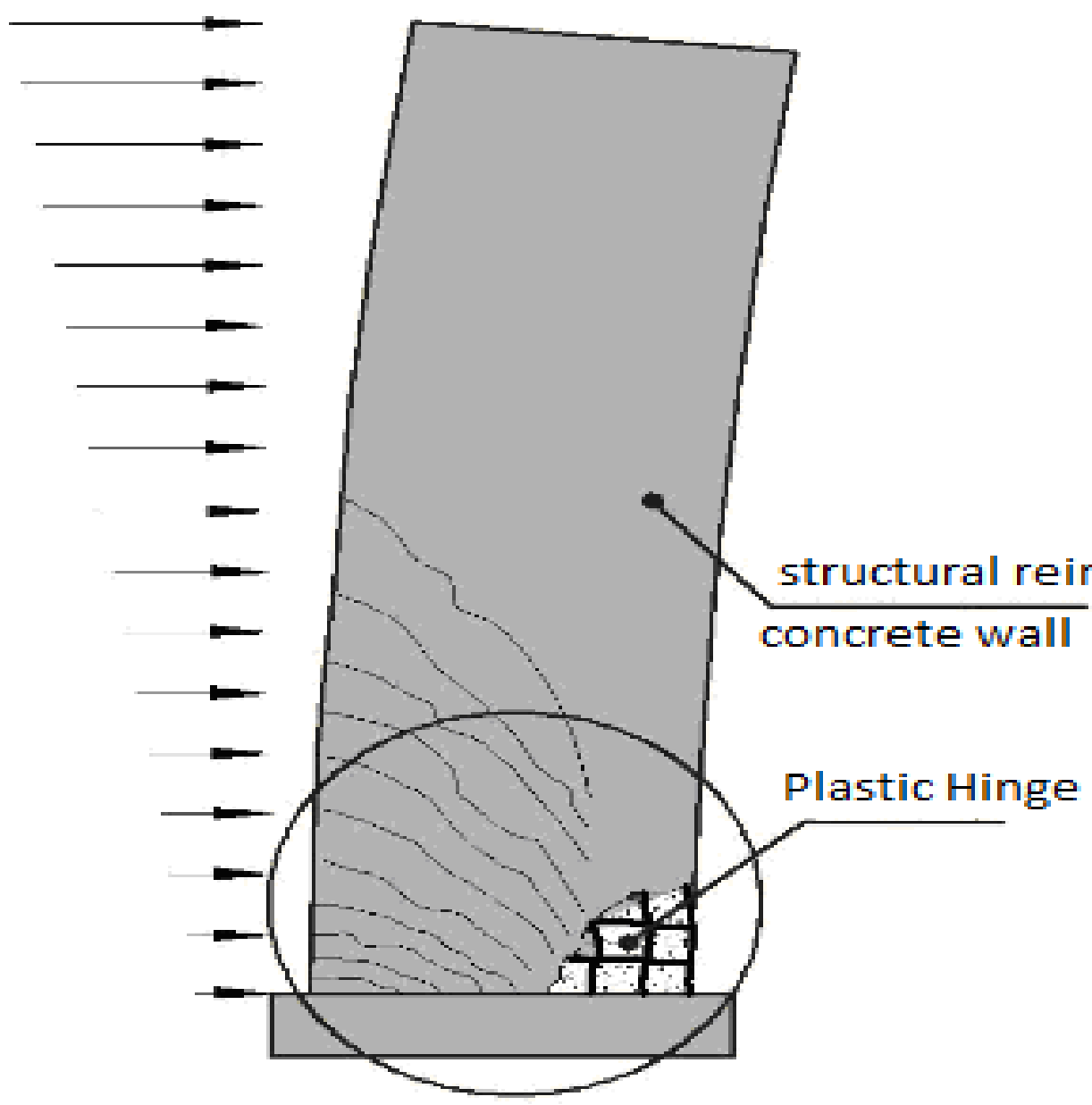

Fig 1.3 Behaviour of shear wall under flexure \& formation of Plastic hinges

The aims and objective of the present study is

To study the relationship between SWA / FA (\%) and Base Shear for all nine models.

To study the effect of SWA / FA \% on Roof displacement for all nine models and

To study the effect of SWA / FA \% on storey displacement for all nine mod

\section{$2.1 \quad$ Introduction:}

\section{LITERATURE REVIEW}

In this chapter we will discuss the different studies which were performed in past in regards to the seismic analysis of multistoried buildings with different shear wall ratios. The discussion comprises of ten previous works which were conducted to show the effect of shear wall ratio on different types of structure and recorded the response plots under some previous earthquake worldwide.

\subsection{Literature Reviews:}

Fintel, M. ${ }^{[3]}(\mathbf{1 9 9 5 )}$ "Performance of buildings with shear walls in earthquakes of the last thirty years." In historical earthquakes reinforced concrete structural walls showed to be very effective in preventing collapse and damage of buildings under strong and frequent events respectively.

Hassan and Sozen ${ }^{[4]}$ (1997) "Seismic Vulnerability Assessment of

Low-Rise Buildings in regions with infrequent earthquakes" A simplified method proposed which enables ranking an inventory of low-rise (up to five stories) monolithic RC buildings based on their seismic vulnerability level from low to high by using column and wall indexes. This method requires only structural dimensions as the input and is based on effective wall and column indexes plotted in a two-dimensional form.

Ersoy (1999) and Tekel ${ }^{[5]}$ (2006) "Seismic strengthening of RC structures with exterior shear walls" In earthquake-resistant design, when a dual system is used, the general approach is using a shear wall area to floor area ratio of about $1.0 \%$ as a rule of thumb. 
Ozan Soydaş ${ }^{[9]}$ (2009) "Evaluation of shear wall indexes for reinforced concrete Buildings" Earthquake ground motions induce lateral forces that cause lateral deformations on both structural and nonstructural components of a building.

\subsection{Introduction:}

\section{METHODOLOGY}

Earthquake and its occurrence and measurements, its vibration effect and structural response have been continuously studied for many years in earthquake history and thoroughly documented in literature. Since then the structural engineers have tried hard to examine the procedure, with an aim to counter the complex dynamic effect of seismically induced forces in structures, for designing of earthquake resistant structures in a refined and easy manner. This re-examination and continuous effort has resulted in several revisions of Indian Standard: 1893: (1962, 1966, 1970, 1975, 1984, and 2002) code of practice on the "Criteria for Earthquake Resistant Design of Structures" by the Bureau of Indian Standards (BIS), New Delhi. the structural engineers must understand the basic design criteria and procedures for determining the lateral forces. Various approaches to seismic analysis have been developed to determine the lateral forces, ranging from purely linear elastic to non-linear inelastic analysis.

\subsection{Methods of Seismic Analysis:}

Seismic analysis is done on structural model to determine the forces induced in the structure due to earthquake. The analysis process can be categorized on the basis of three factors: the type of the externally applied loads, the behavior of structure/or structural materials and the type of structural model selected. Based on the type of external action and behavior of structure, the analysis can be further classified as linear static analysis, linear dynamic analysis, nonlinear static analysis, or non-linear dynamic analysis (Beskos and Anagnostoulos, 1997).

Linear static analysis or equivalent static analysis can only be used for regular structures with limited height. Linear dynamic analysis can be performed in two ways either by mode superposition method or response spectrum method and elastic time history method.This analysis will produce the effect of the higher modes of vibration and the actual distribution of forces in the elastic range in a better way.

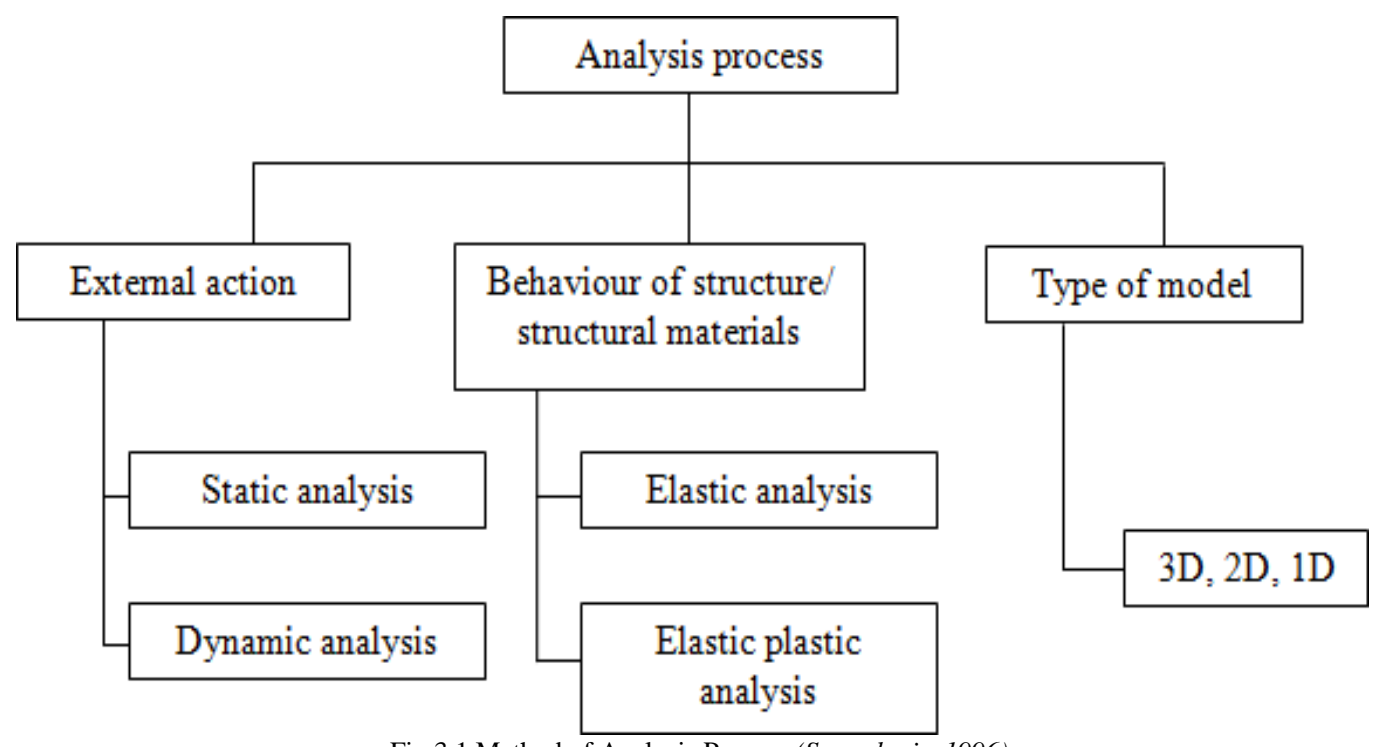

Fig 3.1 Method of Analysis Process (Syrmakezis, 1996)

\subsection{Introduction:}

\section{CASE STUDY}

Most building codes prescribe the method of analysis based on whether the building is regular or irregular. Almost all the codes suggest the use of static analysis for symmetric and selected class of regular buildings. For buildings with irregular configurations, the codes suggest the use of dynamic analysis procedures such as response spectrum method or time history analysis.

In the present study lateral load analysis is performed on twelve buildings models that have five eight and twelve stories with the same plans but different shear wall area ratios are generated for the application of Response Spectrum and Linear Static analysis. The Shear wall area ratio is determined by dividing the total shear wall area in one principal direction to the plan area of the ground floor $\left(\sum \mathrm{Aw} / \mathrm{Ap}\right)$. 
Description of the Building Models:

\begin{tabular}{|l|r|l|l|}
\multicolumn{5}{c}{ Table 4.1 Description of Building Models } \\
\hline \multirow{2}{*}{ Model } & $\begin{array}{l}\text { Number } \\
\text { of } \\
\text { Storey }\end{array}$ & $\begin{array}{l}\text { SWA / FA \% } \\
\text { Direction }\end{array}$ & $\begin{array}{l}\text { Y - } \\
\text { Direction }\end{array}$ \\
\hline Model 1 & 5 & 0.93 & 0.54 \\
Model 2 & 5 & 1.2 & 0.70 \\
Model 3 & 5 & 1.47 & 0.85 \\
\hline & 9 & 0.93 & 0.54 \\
Model 1 & 9 & 1.2 & 0.70 \\
Model 2 & 9 & 1.47 & 0.85 \\
Model 3 & & & \\
\hline & 12 & 0.93 & 0.54 \\
Model 1 & 12 & 1.2 & 0.70 \\
Model 2 & 12 & 1.47 & 0.85 \\
Model 3 & & \multicolumn{3}{l}{} \\
\hline
\end{tabular}

\section{Description of the Building Models:}

Table 4.1 Description of Building Models

\begin{tabular}{|l|r|l|l|}
\hline \multirow{2}{*}{ Model } & $\begin{array}{l}\text { Number } \\
\text { of } \\
\text { Storey }\end{array}$ & $\begin{array}{l}\text { SWA / FA \% } \\
\text { Direction }\end{array}$ & $\begin{array}{l}\text { Y - } \\
\text { Direction }\end{array}$ \\
\hline Model 1 & 5 & 0.93 & \\
Model 2 & 5 & 1.2 & 0.54 \\
Model 3 & 5 & 1.47 & 0.70 \\
\hline & & & 0.85 \\
Model 1 & 9 & 0.93 & 0.54 \\
Model 2 & 9 & 1.2 & 0.70 \\
Model 3 & 9 & 1.47 & 0.85 \\
\hline & & & 0.54 \\
Model 1 & 12 & 0.93 & 0.70 \\
Model 2 & 12 & 1.2 & 0.85 \\
Model 3 & 12 & 1.47 & \\
\hline
\end{tabular}

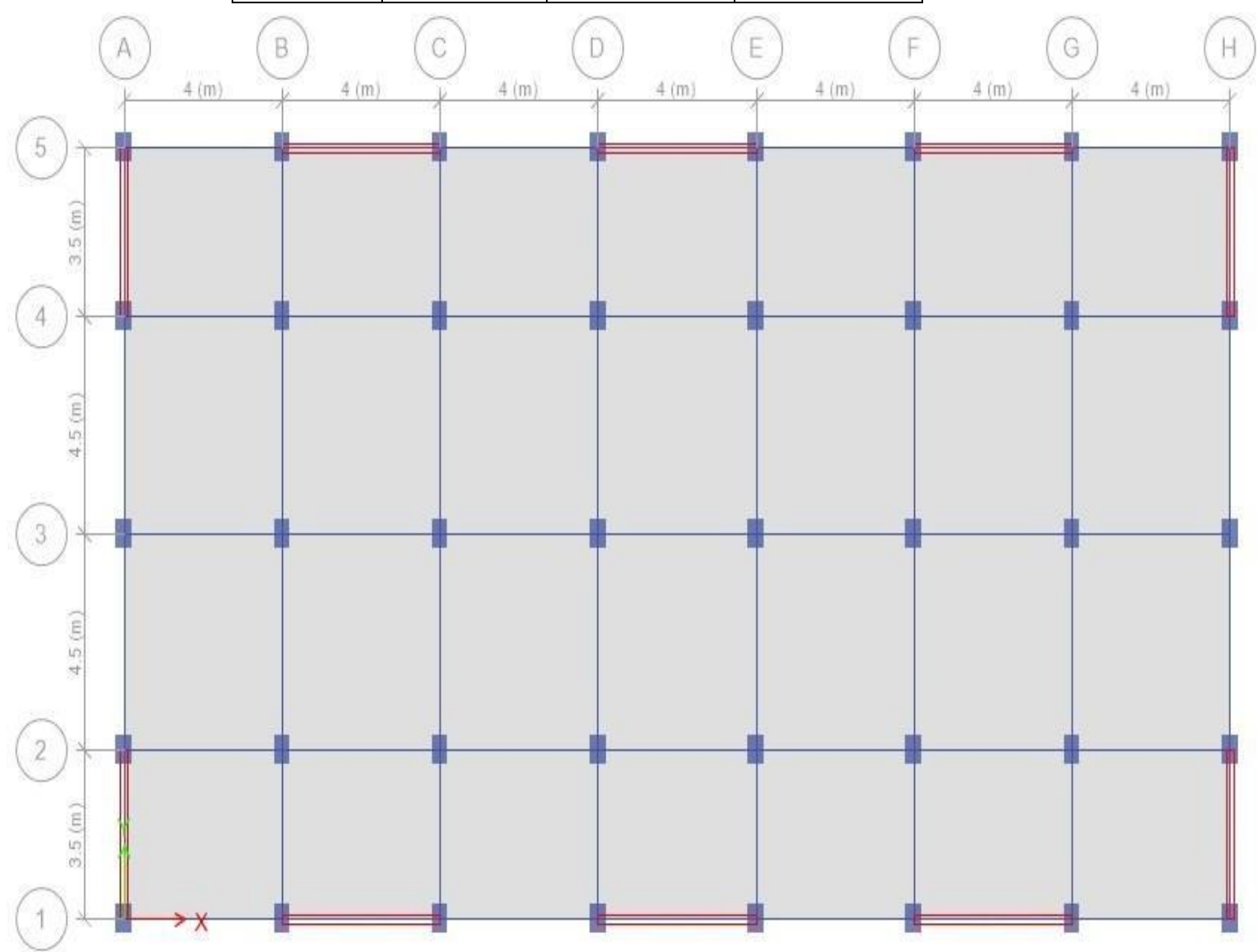

Fig 4.1 Plan layout of Five Storey Building Models 

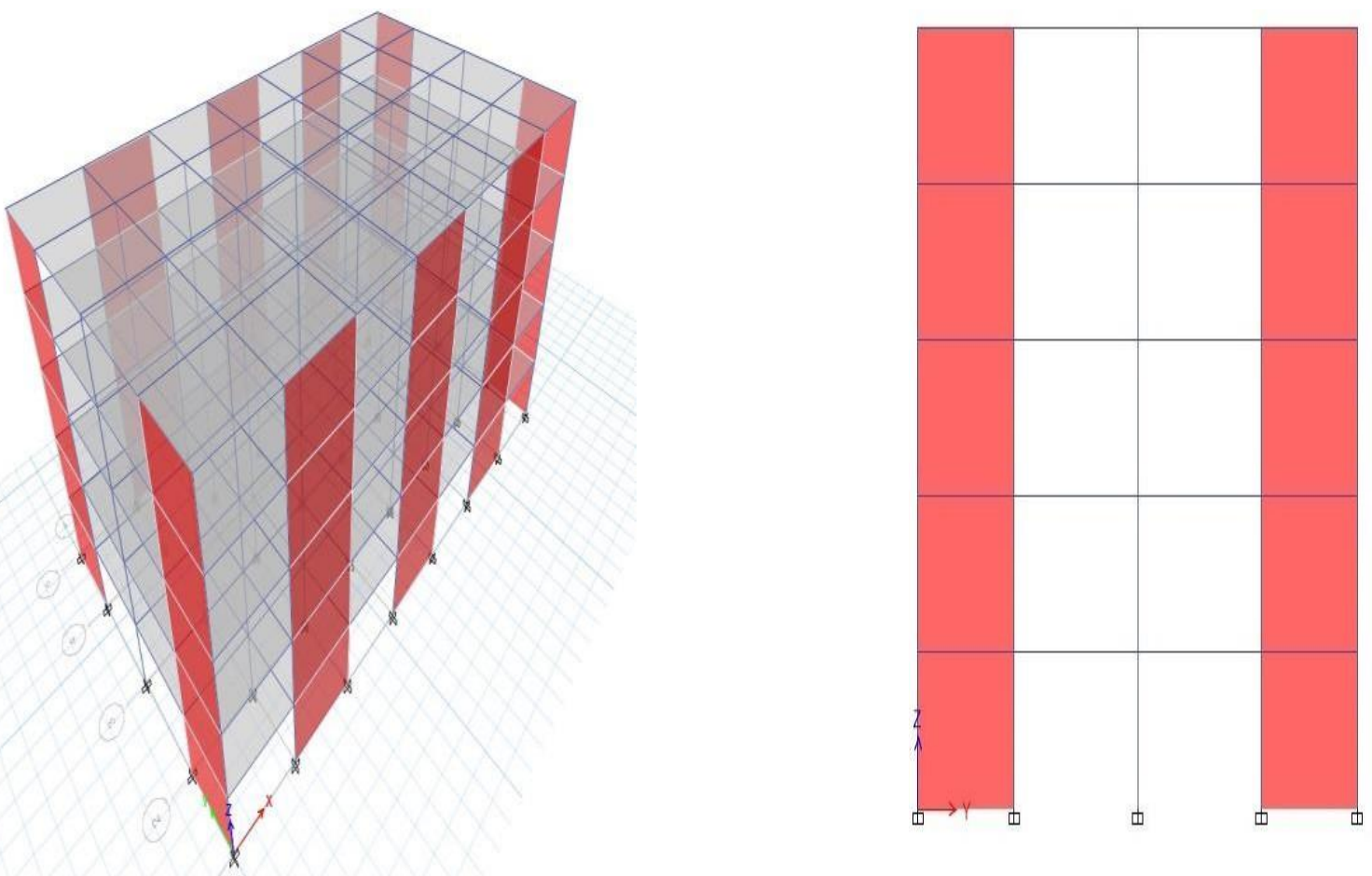

Fig 4.2 Isometric View and Front Elevation of Five Storey Building Model

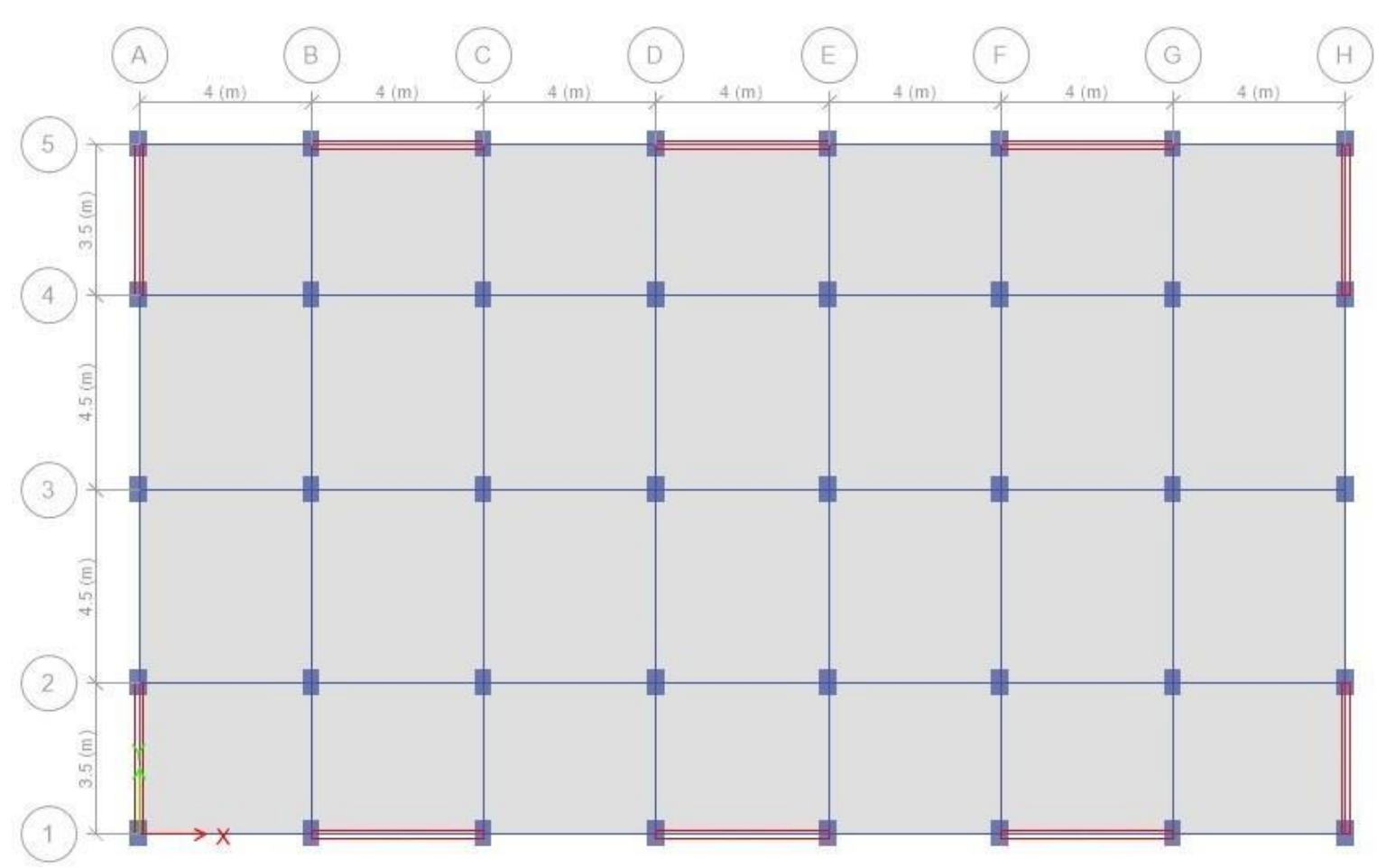

Fig 4.3 Plan Layout of Nine Storey Building Models 

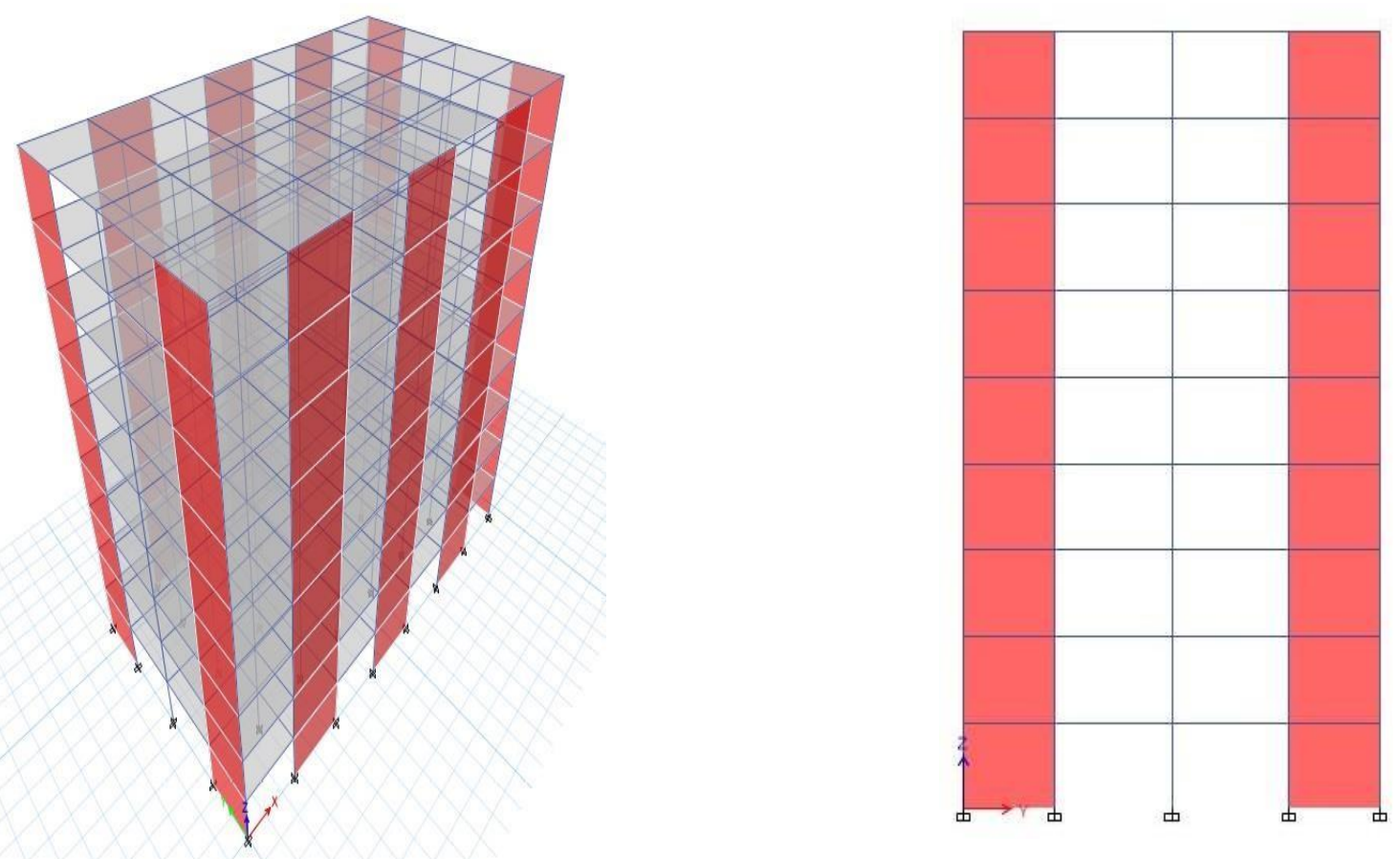

Fig 4.4 Isometric View and Front Elevation of Nine Storey Building Model

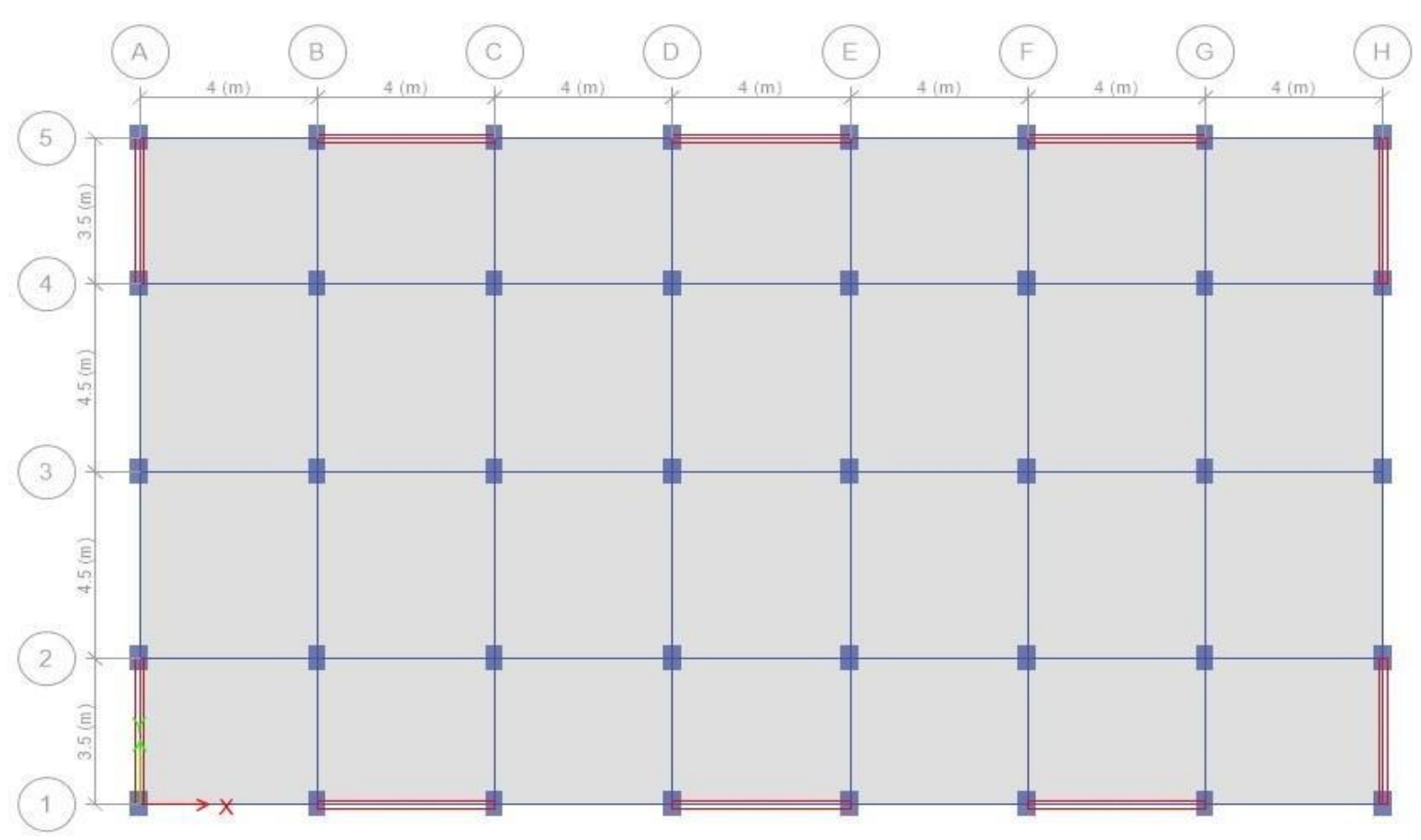

Fig 4.5 Plan Layout of Twelve Storey Building Models 

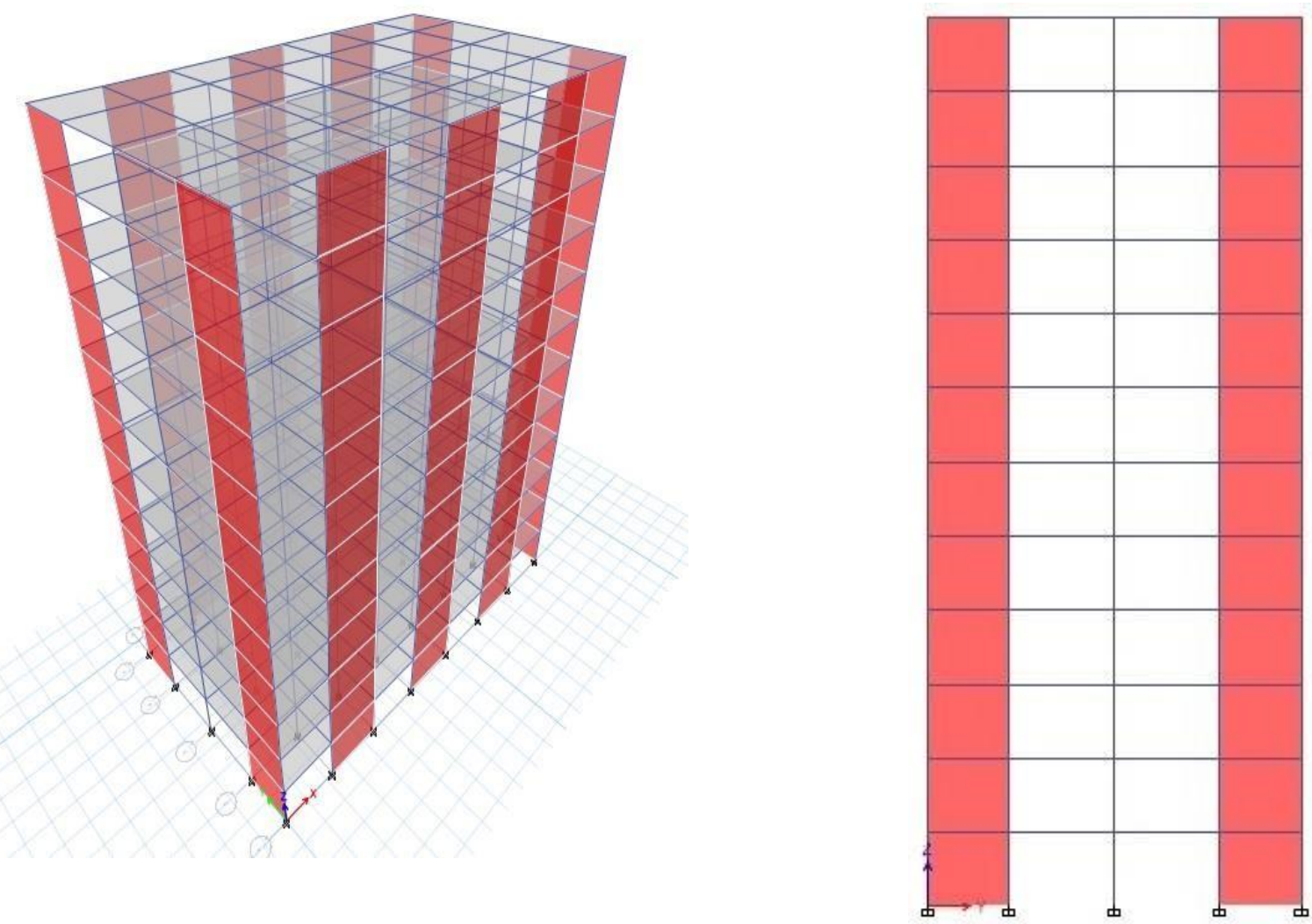

Fig 4.6 Isometric View and Front Elevation of Twelve Storey Building Model

Design Data:

\section{Material Properties:}

Young's modulus of (M25) concrete,E Density of Reinforced Concrete

$$
\begin{aligned}
= & 22.360 \times 10^{6} \mathrm{kN} / \mathrm{m}^{2} \\
= & 25 \mathrm{kN} / \mathrm{m} \\
= & 3500 \times 103 \mathrm{kN} / \mathrm{m}^{2}
\end{aligned}
$$

Density of brick masonry $=19.2 \mathrm{kN} / \mathrm{m}^{3}$

Assumed Dead load intensities

Floor finishes $=1.5 \mathrm{kN} / \mathrm{m}^{2}$

Live load $\quad=4 \mathrm{kN} / \mathrm{m}^{2}$

Member properties:

Thickness of Slab

Column size

Beam size

$$
\begin{aligned}
& =0.125 \mathrm{~m} \\
& =(0.4 \mathrm{mx} 0.6 \mathrm{~m}) \\
& =(0.250 \mathrm{~m} \times 0.450 \mathrm{~m}) \\
& =0.230 \mathrm{~m} \\
& =0.175,0.225,0.275 \mathrm{~m}
\end{aligned}
$$

Thickness of wall

Thickness of shear wall

Earthquake Live Load on Slab as per clause 7.3.1 and 7.3.2 of IS 1893 (Part-I) - 2002 is calculated as:

Roof (clause 7.3.2)

Floor (clause 7.3.1)

$$
=0
$$$$
=0.5 \times 4=2 \mathrm{kN} / \mathrm{m}^{2}
$$ 

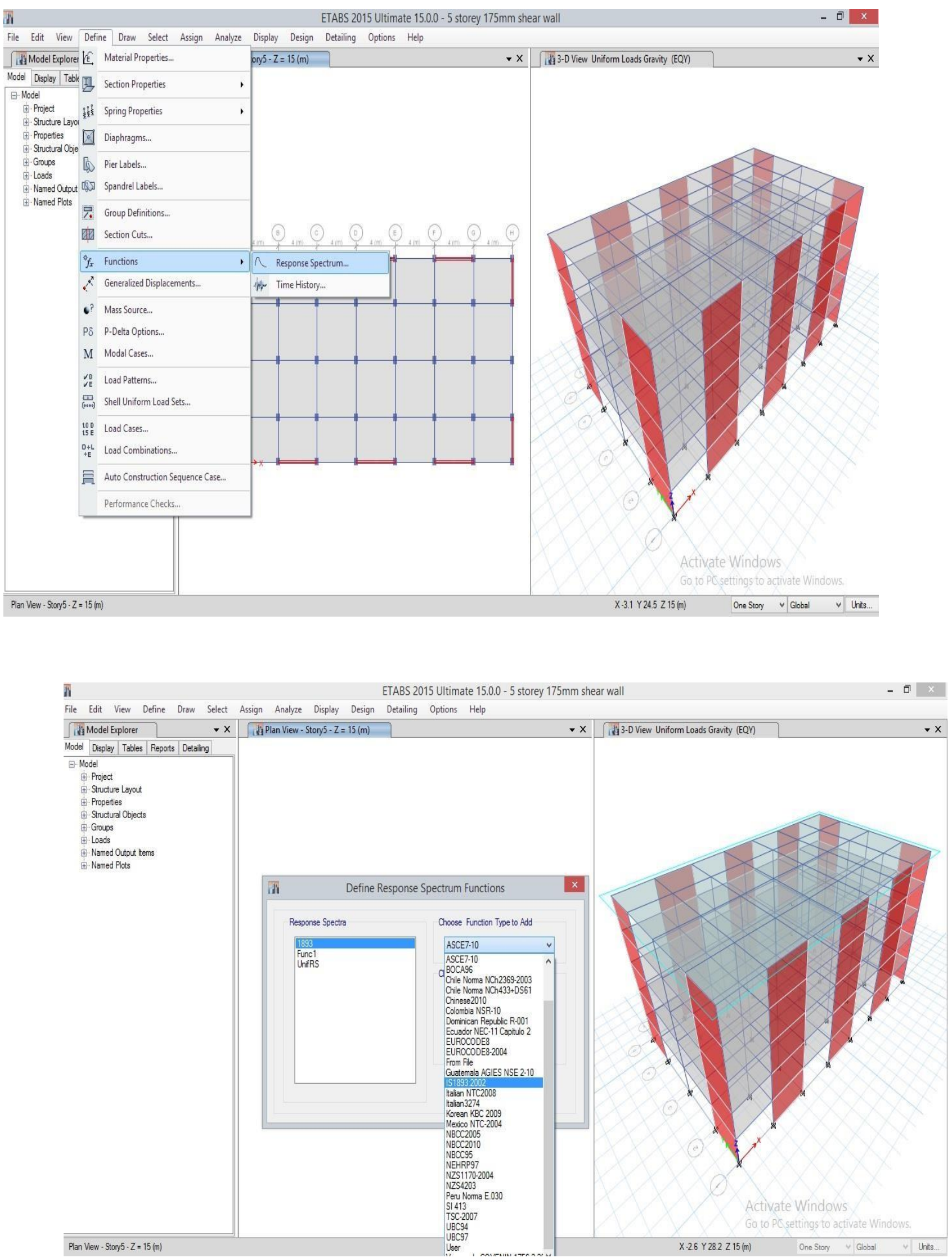


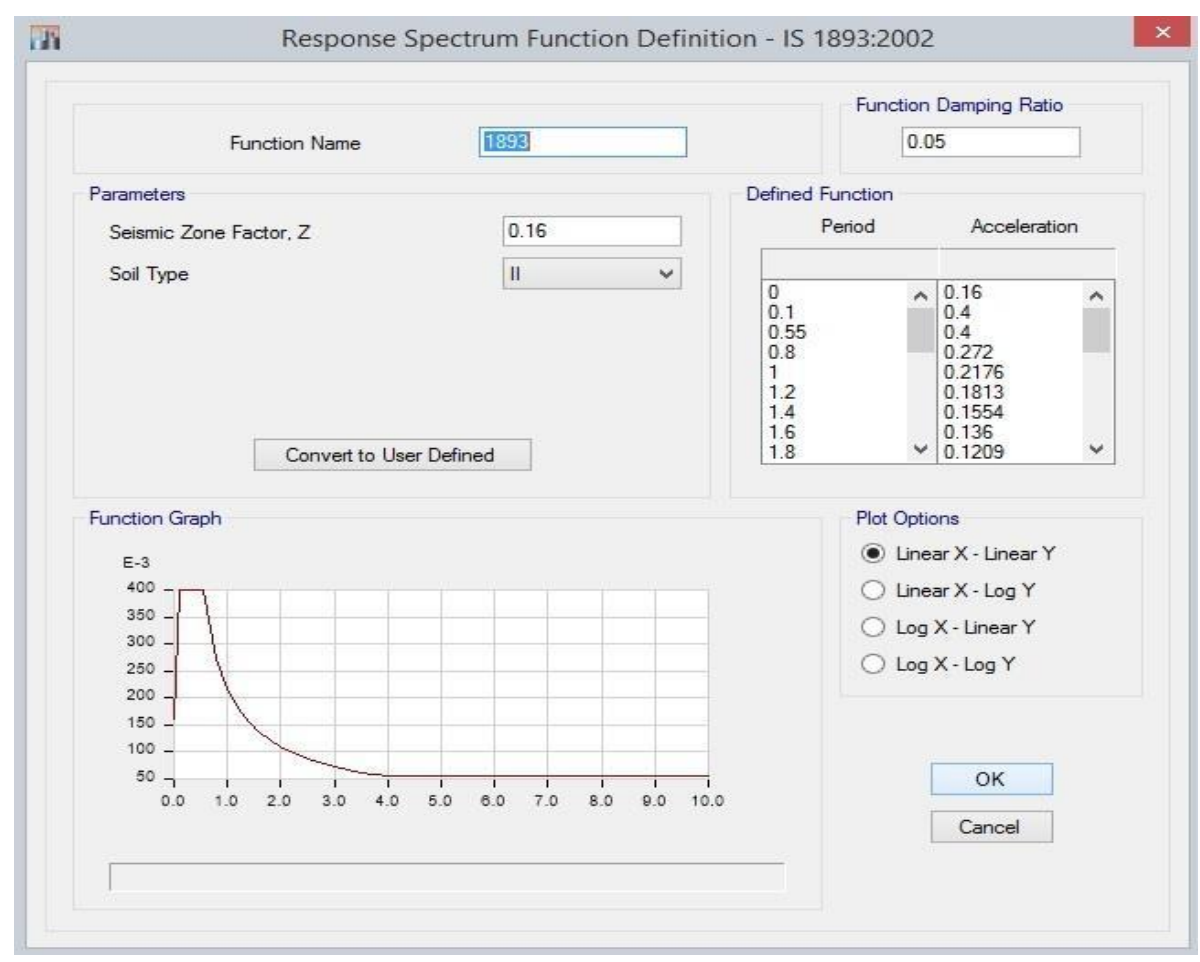

RESULTS AND DISCUSSION

5.1 Introduction:

In this chapter, the results of the 5,9 and 12 storey building models are presented and discussed in detail. The result includes of all building models which are computed using the Response Spectrum Analysis and Linear Static Analysis. The analysis of the different building models is performed by using E-TABS analysis package.

The results of Fundamental natural period of vibration, relationship between shear wall area and Base shear, relationship between shear wall area and roof displacement and storey displacement for the different building models for each of the above analysis are presented and compared. An effort has been made to study the effect of shear wall area to floor area ratio by considering ground floor as soft storey in the analysis

\section{RESULTS:}

RESPONSE SPECTRUM ANALYSIS:

Table 5.1 Codal and Analytical Fundamental natural periods for different building models along longitudinal - direction

\begin{tabular}{|l|c|l|l|}
\hline \multicolumn{4}{|l|}{ Fundamental Natural Period T (sec) } \\
\hline Model & $\begin{array}{l}\text { Number } \\
\text { of story }\end{array}$ & Codal & Analytical \\
\hline Model 1 & 5 & 0.329 & 0.393 \\
Model 2 & 5 & 0.329 & 0.378 \\
Model 3 & 5 & 0.329 & 0.367 \\
\hline & & & \\
Model 1 & 9 & $0 . .621$ & 0.71 \\
Model 2 & 9 & $0 . .621$ & 0.698 \\
Model 3 & 9 & $0 . .621$ & 0.673 \\
\hline & & & \\
Model 1 & 12 & 0.789 & 1.12 \\
Model 2 & 12 & 0.789 & 1.09 \\
Model 3 & 12 & 0.789 & 1.07 \\
\hline
\end{tabular}


Table 5.2 Codal and Analytical Fundamental natural periods for different building models along transverse direction.

\begin{tabular}{|l|l|l|l|}
\hline \multicolumn{3}{|l|}{ Fundamental Natural Period T (sec) } \\
\hline \multicolumn{3}{|l|}{} \\
\hline Model & $\begin{array}{l}\text { Number } \\
\text { of story }\end{array}$ & Codal & Analytical \\
\hline Model 1 & 5 & 0.371 & 0.393 \\
Model 2 & 5 & 0.371 & 0.378 \\
Model 3 & 5 & 0.371 & 0.367 \\
\hline & & & \\
Model 1 & 9 & 0.621 & 0.71 \\
Model 2 & 9 & 0.621 & 0.698 \\
Model 3 & 9 & 0.621 & 0.673 \\
\hline & & & \\
Model 1 & 12 & 0.89 & 1.12 \\
Model 2 & 12 & 0.89 & 1.09 \\
Model 3 & 12 & 0.89 & 1.07 \\
\hline
\end{tabular}

5.1.1 Shear Wall Area to Floor Area Ratio (SWA / FA) \% vs. Base Shear

Fig 5.1 SWA / FA (\%) vs. Base Shear of Five, Nine and Twelve Storey - Seismic Force in X-Direction
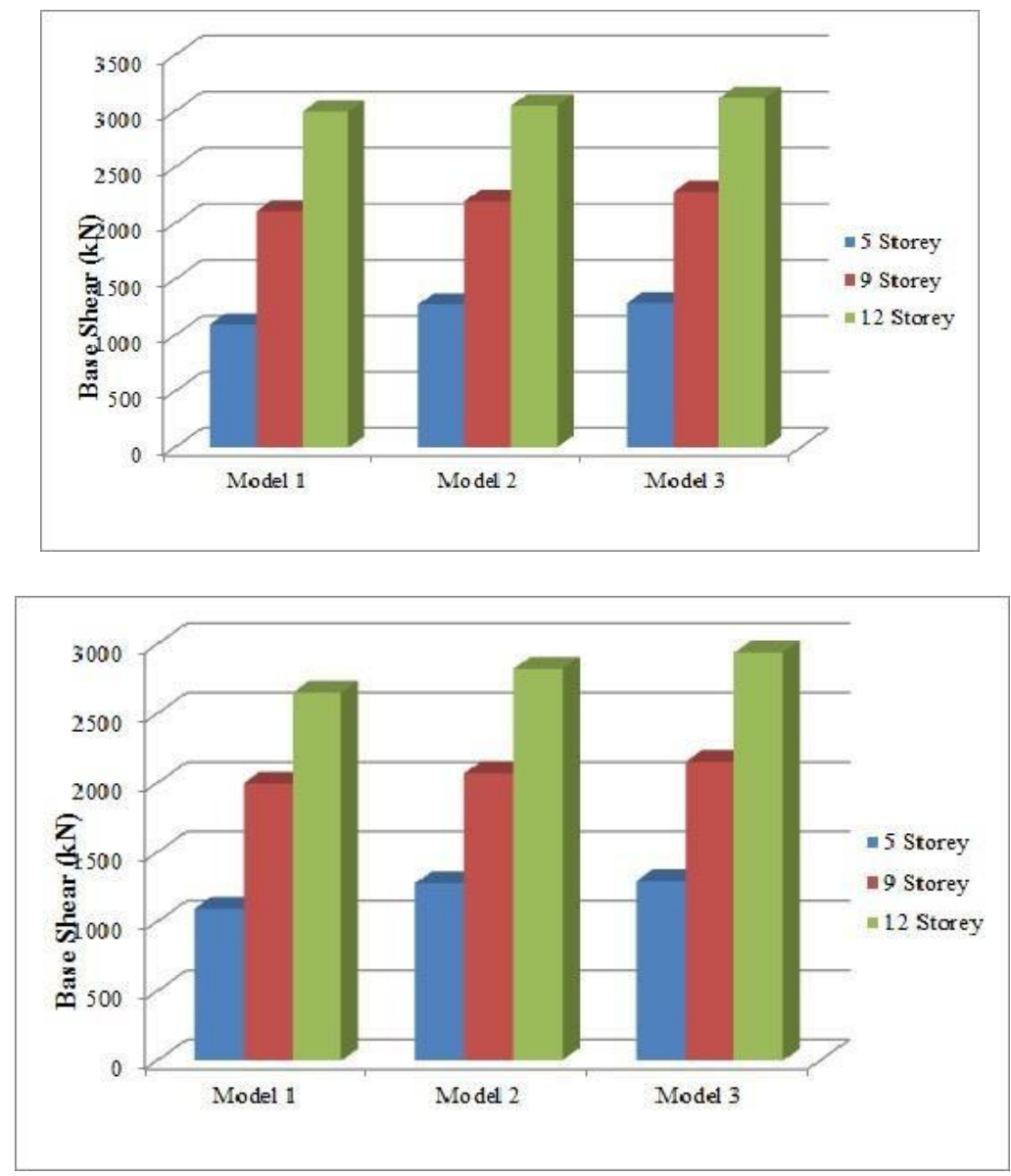

Fig 5.2 SWA / FA (\%) vs. Base Shear of Five, Nine and Twelve Storey - Seismic Force in Y-Direction 
5.1.2

Shear Wall Area to Floor Area Ratio (SWA / FA) \% vs. Roof Displacement:

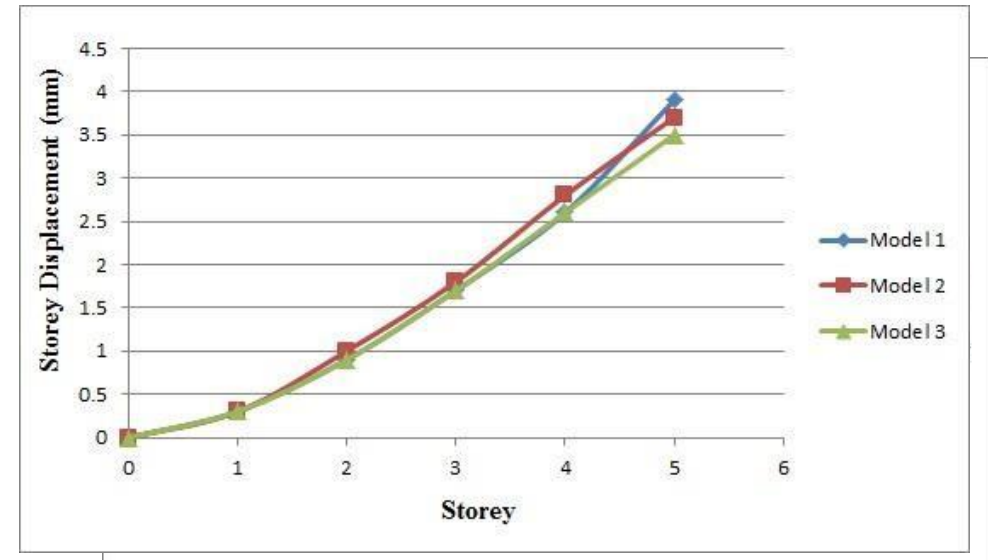

Fig 5.3 SWA / FA \% vig. 5.6.Storey Displacement of Five Storey Model-Seismic Force in Y-Pirection - Sisplacentent of Five, Nine and Twelve Storey Modef-Seismic Force in X-Direction

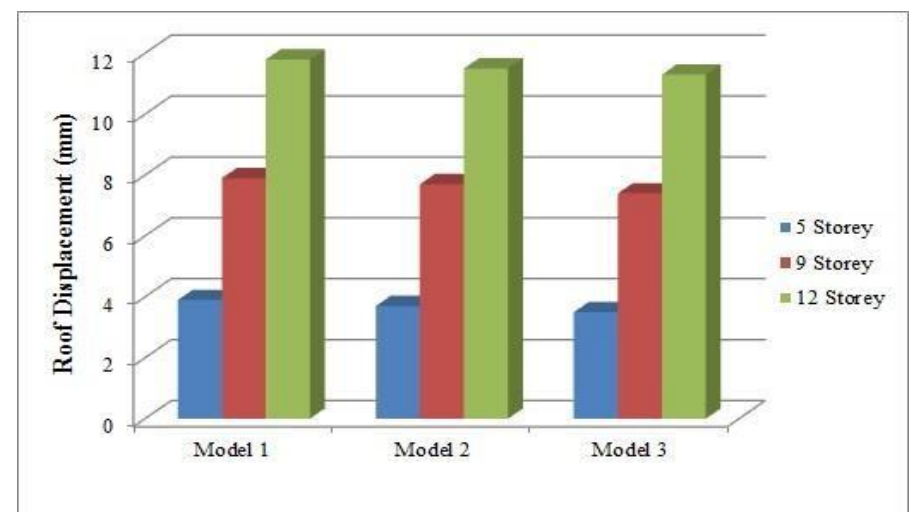

Fig 5.4 SWA / FA \% vs. Roof Displacement of Five, Nine and Twelve Storey Models-Seismic Force in Y- Direction 5.1.1 Storey Displacement:

- $\quad$ Five storey model

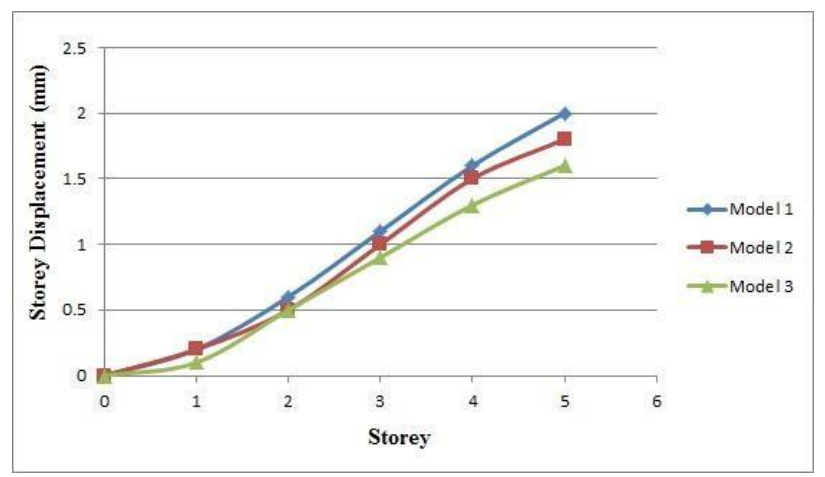

Fig 5.5 Storey Displacement of Five Storey Model - Seismic Force 


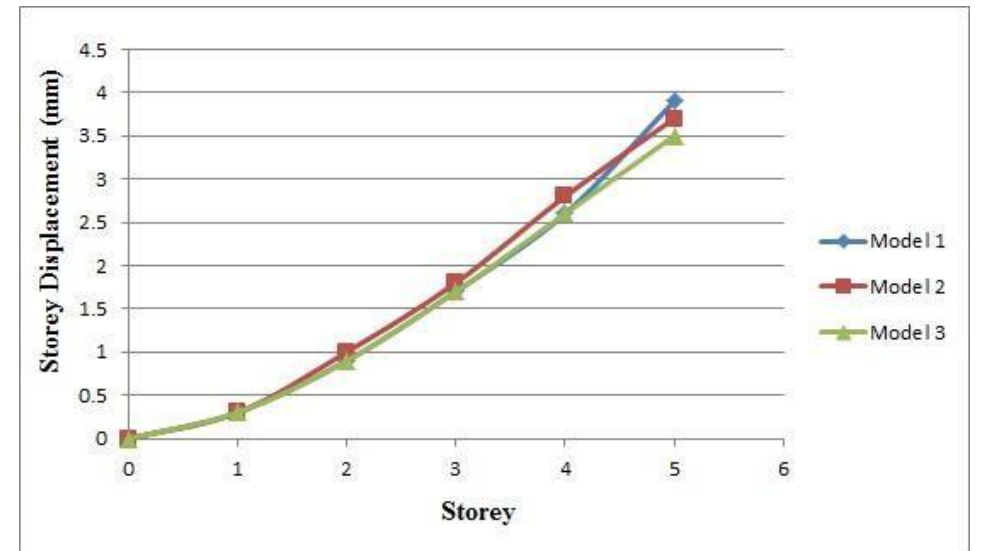

Fig 5.6 Storey Displacement of Five Storey Model - Seismic Force in Y-Direction Nine storey model:

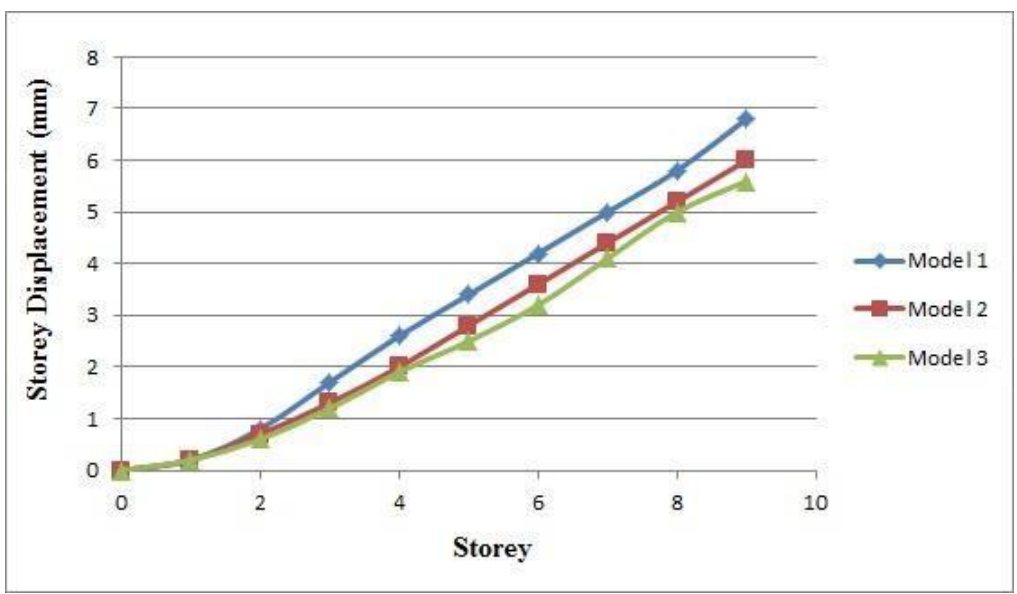

5.7 Storey Displacement of Nine Storey Model - Seismic Force in X-Direction

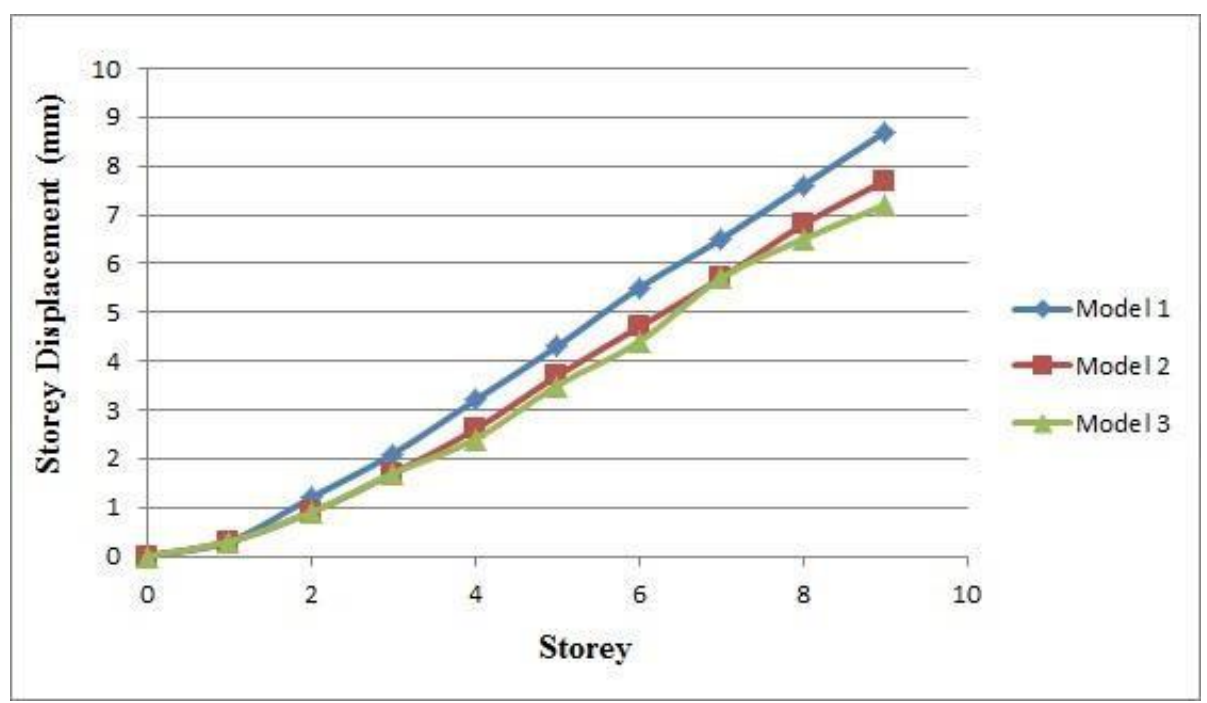

Fig 5.8 Storey Displacement of Nine Storey Model - Seismic Force in Y-Direction 
Twelve storey model:

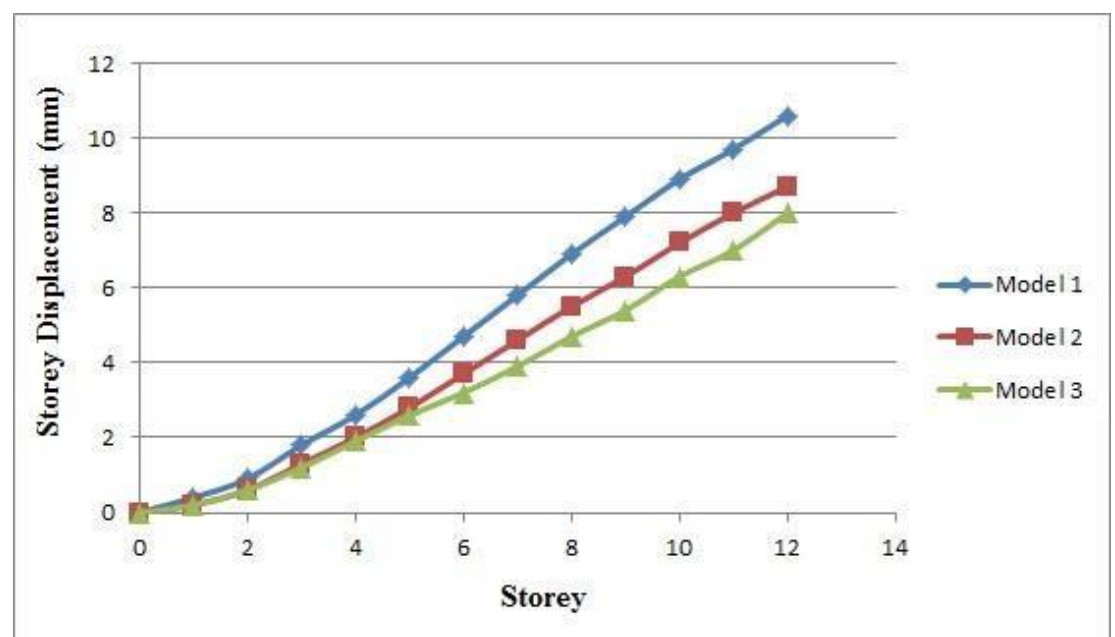

Fig 5.9 Storey Displacement of Twelve Storey Model - Seismic Force in X- Direction

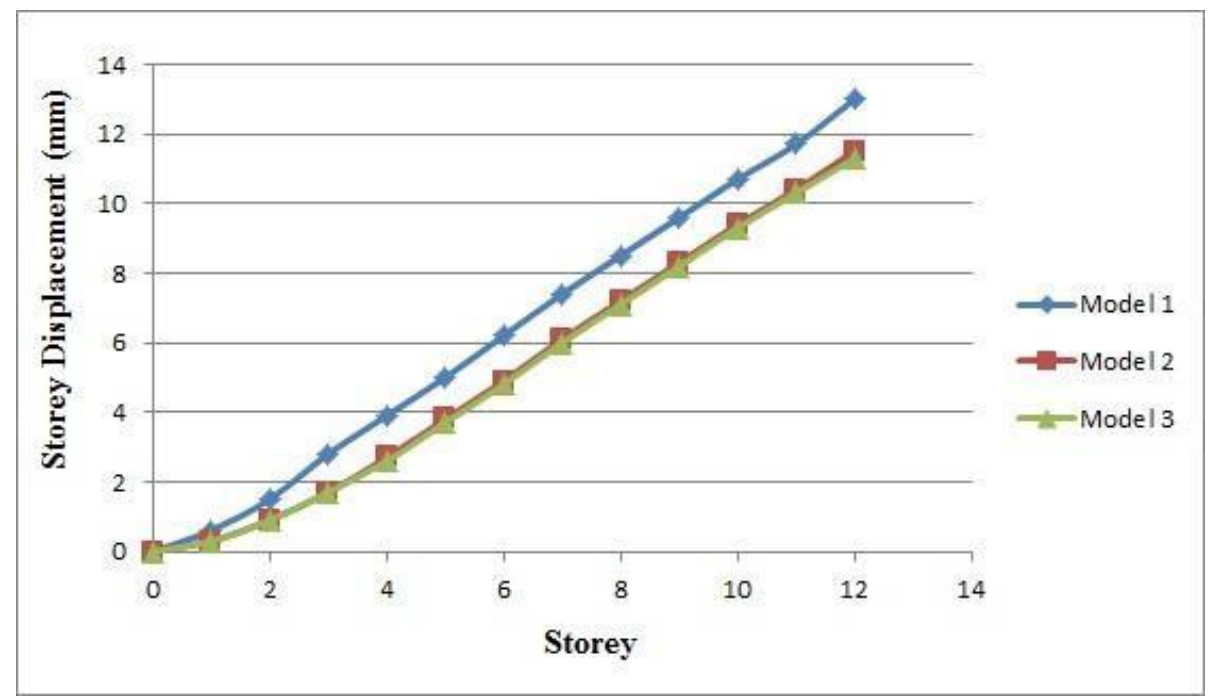

Fig 5.10 Storey Displacement of Twelve Storey Model -Seismic Force in Y-Direction

\section{Shear Wall Area to Floor Area Ratio (SWA / FA) \% vs. Base Shear}

In this case the relationship between SWA / FA \% and Base shear has been studied. The \% of shear wall area ratios are taken on $\mathrm{x}$-axis and the base shears is taken on $\mathrm{y}$ - axis.

- $\quad$ The observations made through this study is, for five storey building models, for both $\mathrm{X}$ and $\mathrm{Y}$, initially the base shear is less when SWA / FA \% $=0.93 \%$ (X) $0.54 \%$ (Y).

- $\quad$ When the shear wall area ratio increases the base shear is also increases. For buildings with $1.2 \%(\mathrm{X}) 0.7 \%(\mathrm{Y})$ and $1.47 \%(\mathrm{X}) 0.85 \%(\mathrm{Y}) \mathrm{SWA} / \mathrm{FA} \%$, the shear wall contribution in the base shear is observed to be slightly higher than that of 0.70 and 0.91 SWA / FA \%.

Thus this indicates that as the SWA / FA \% increases base shear also increases. In case of nine and twelve storey building models similar pattern can be observed. 


\section{Shear Wall Area to Floor Area Ratio (SWA / FA) \% vs. Roof Displacement}

In this case the relationship between SWA / FA \% vs. Roof displacement has been studied. The \% of shear wall area ratios is taken on $\mathrm{x}$-axis and the displacements are taken on $\mathrm{y}$-axis.

- $\quad$ It can be observed that for 5-storey building model, the difference in roof displacement is not much significant, especially for $0.93 \%$ (X) $0.54 \%$ (Y) SWA / FA \%.

- $\quad$ A significant decrease in roof displacement can be observed with SWA / FA\% $=1.2 \%(\mathrm{X}) 0.7 \%(\mathrm{Y})$, which indicates that at least $1.2 \%(\mathrm{X}) 0.7 \%(\mathrm{Y})$ of shear wall ratio should be used in design.

- $\quad$ In case of nine and twelve storey building models similar pattern can be observed in roof displacement

5.2.2

Storey Displacement:

In this case the variation of story displacement is examined by Linear Static Analysis with increasing shear wall area ratios, by taking storey on $\mathrm{x}$-axis and displacement on $\mathrm{y}$-axis.

- $\quad$ It was observed that as the height increases the displacements are also increases, but by increasing the SWA / FA $\%$ the displacements values decreases. In case 5 - storey building model when SWA / FA $\%=0.93 \%$ (X) $0.54 \%$ (Y), maximum displacement are observed as expected.

(Y) shear wall ratios.

- $\quad$ A significant decrease in displacement with increasing shear wall area to floor area ratios between $1.2 \%(\mathrm{X}) 0.7 \%$ $(\mathrm{Y})$ and $1.47 \%(\mathrm{X}) 0.85 \%(\mathrm{Y})$ is observed, which indicates that at least $1.2 \%(\mathrm{X}) 0.7 \%(\mathrm{Y})$ of shear wall ratio should be used in design.

- $\quad$ However, a shear wall ratio less than $0.93 \%$ (X) $0.54 \%$ (Y) is not sufficient to limit the observed displacement. Similar effects can be seen in nine and twelve storey models also.

5.3 Summary:

In this chapter, the results obtained from Response Spectrum Analysis performed by using E-tabs includes relationship between shear wall area and Base shear, relationship between shear wall area and Roof displacement and Storey Displacements has been discussed for different building model with increasing Shear wall area ratio by considering the ground floor as soft storey.

\section{CONCLUSIONS AND SCOPE FOR FURTHER STUDY}

\subsection{Conclusions}

On the basis of the results of the analytical investigation of 5, 9 and 12 storey RC building models with increasing shear wall to floor area ratio (SWA / FA) \% by considering the ground floor as soft storey, the following conclusions are drawn:

- In case of response spectrum analysis it is observed that base shear values are increasing with increase in SWA / FA $\%$ for all the models.

- $\quad$ For SWA / FA $\%=0.93 \%(\mathrm{X}) 0.54 \%(\mathrm{Y})$ a significant decrease in roof displacement is observed as compared to lower SWA / FA \%. The decrease in roof displacements becomes less pronounced with increase in SWA / FA \% beyond $1.2 \%$ (X) $0.7 \%(\mathrm{Y})$. This indicates that SWA / FA \% of $1.2 \%(\mathrm{X}) 0.7 \%(\mathrm{Y})$ is effective in reducing the roof displacements.

- $\quad$ Storey Displacement case of Response Spectrum indicates that, the decrease in displacement with increasing shear wall area to floor area ratios is in between $1.2 \%(\mathrm{X}) 0.7 \%(\mathrm{Y})$.

- $\quad$ It is observed that from Response spectrum that the storey drift decreases with increase in SWA/FA \%.

\section{SCOPE FOR FURTHER STUDY}

Studies can be conducted on high rise buildings (Multistoried) by providing more thickness of shear walls, providing shear wall at various other locations and also by providing dual system, which consists of shear wall (or braced frame) and moment resisting frame.The study can also be done on Sloping grounds, various damping mechanisms and its applications on structures, and also by conducting the structures having base isolation system. 


\section{REFERENCES}

[1] iddell et al. ${ }^{\text {[1] }}$ (1987). "General features of the buildings located in Vina del Mar that experienced the 1985 Chile earthquake".

[2] Dr. Jain k. Explanatory example on Indian seismic code IS-1893 (Part-1).

[3] Fintel, M. ${ }^{[3]}(\mathbf{1 9 9 5})$ "Performance of buildings with shear walls in earthquakes of the last thirty years.

[4] Hassan and Sozen ${ }^{[4]}$ (1997), "Seismic Vulnerability Assessment of Low-Rise Buildings in regions with infrequent earthquakes.

[5] Gulkan and Utkutug ${ }^{[7]}$ (2003), "The relationship between roof drift and shear wall ratio by taking into account the shear wall aspect ratio".

[6] Sharany Haque, khan Mahmud Amanat: Seismic Vulnerability of Columns of RC frame Buildings with Soft ground Storey.

[7] Earthquake Resistant Design of Structures: by Pankaj Agarwal and Manish Shrikhande. 